Journal of Economics, Finance and Accounting Studies (JEFAS)

ISSN: $2709-0809$

DOI: $10.32996 /$ jefas

Journal Homepage: www.al-kindipublisher.com/index.php/jefas

\title{
The Role of Corporate Governance as Moderating Variable Between Capital Structure and Mining Company Performance
}

\author{
Marselino Wau $\square$ Yohanes Dakhi ${ }^{2}$ and Kristiurman Jaya Mendrofa ${ }^{3}$ \\ ${ }^{123}$ Universitas Nias Raya, Indonesia \\ $\square$ Corresponding Author: Marselino Wau, E-mail: waumarselino561@gmail.com
}

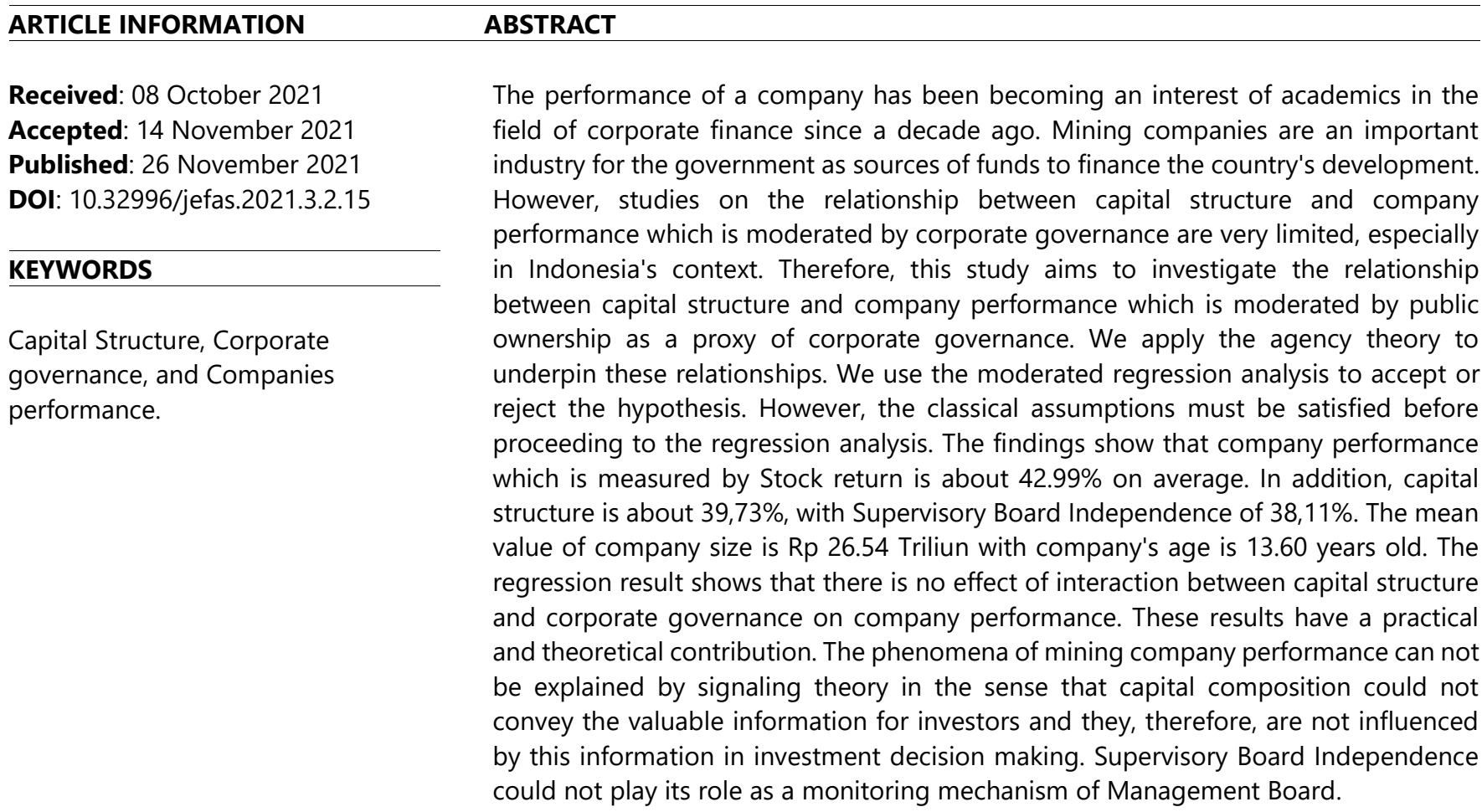

\section{Introduction}

Corporate governance is very important in influencing the company's income capital. If the corporate governance is good, automatically, the capital that will be obtained is optimal. Not only that, good corporate governance can increase the economic improvement of the company itself. Everything can run smoothly if the corporate governance is successful. Corporate governance is also a major influence on sustainable development and economic growth, which adds to the corporate sector's strength and understands more ability to attract capital for special economies (Asyyati, 2021).

According to Kaplan and Norton (1992), one of the problems in corporate governance is planning, coordination, granting mandates, and how to make corporate economic policy decisions by stakeholders in the company. Every company has its vision and mission. Of course, with the vision and mission, the company has a direction and purpose. But to achieve this, strong collaboration between stakeholders is needed and, of course, with good corporate governance. The mining industry is very important for every country as a fuel that is used as an alternative energy source. For example, coal makes a large enough contribution to the progress of a country's economy. This is due to requests from other countries to export coal mining products from Indonesia. The controversial empirical results on this topic can be attributable to a lack of attention to the interaction between capital structure and other corporate governance variables Rocca (La Rocca, 2007).

Copyright: (C) 2021 the Author(s). This article is an open access article distributed under the terms and conditions of the Creative Commons Attribution (CC-BY) 4.0 license (https://creativecommons.org/licenses/by/4.0/). Published by Al-Kindi Centre for Research and Development, London, United Kingdom. 
This potential is what makes mining industry companies stand in Indonesia so that the performance of mining industry companies is partly good and some are not, of course still not maximizing the welfare of the shareholders. To see the good and bad of a company, it can be seen from the company's performance. Company performance is a picture of the company's financial condition which measured by financial ratio analysis, as well as knowing the ability of the company's financial condition that reflects work performance in a certain period. This is very important so that resources are used optimally. Company performance is also used to measure how efficient and effective management is in achieving company goals. Company performance is an important dimension in management research. Company performance can be divided into several groups of definitions, one of which is the ultimate goal of managing the company Meixell and Luoma (Shleifer \& Vishny, 1997).

Company funding that comes from own capital is still lacking, it is necessary to consider company funding from outside, namely debt Corporate governance is defined to include the factors that give rise to the successful operation of the organization. These factors include structure, process, culture, and system. In the view of Deakin and Hughes (1997) corporate governance relates to the relationship between internal corporate governance mechanisms and the public's conception of the scope of corporate accountability.

The handling of this conflict is in dire need of a good corporate governance mechanism. From the definitions above it is clear that corporate governance concerns structures, principles, procedures, and systems that reduce the potential for conflict between the parties and in the long run, maximize the value of the interested parties as a result of the separation of ownership from the parties. interested party. Therefore, this study adds to the existing literature on corporate governance and examines its relationship to the capital structure and ownership structure of DV; company performance (SR), IV; capital structure )DAR), MV; Supervisory Board Independence (composition), CV; Company age (CA), and company size (CS)

According to research Susan [5], The company's financial performance as measured by ROA has a positive and significant effect on manufacturing companies listed on the Indonesia Stock Exchange. Firm size has a positive and insignificant effect on firm value in manufacturing companies listed on the Indonesia Stock Exchange.

Therefore, this study aims to determine the role of corporate governance as a moderator variable between capital structure and mining company performance. Thus, the proposed research framework is shown in Figure 1. This research paper is structured as follows: the first session is the background of the study. The second session discussed materials and methods. The next third session is about the results and discussion. the last session discussed the conclusions and recommendations.

Figure 1. Research Framework

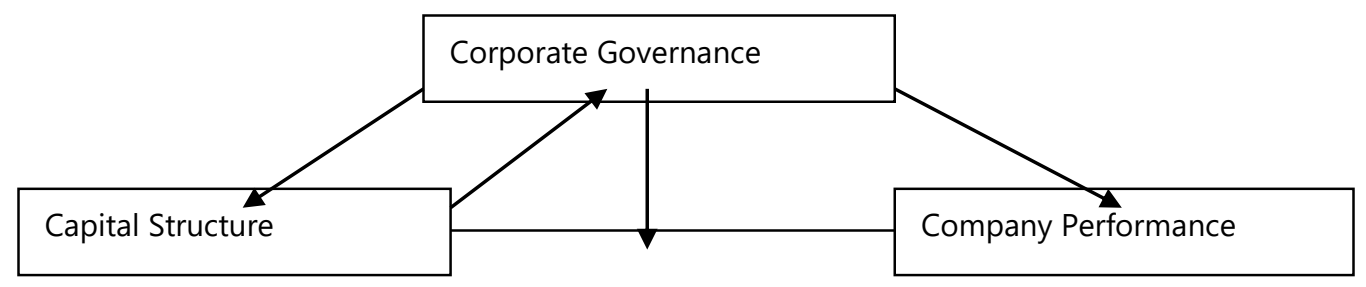

a. Mediation role of the corporate governance in the relation between capital structure and company performance

b. Moderation role of the corporate governance in the relation between capital structure and company performance

c. Role of the corporate governance ad determinant of the capital structure

\subsection{Company Performance}

Company performance is a description of the company's financial condition as measured by financial ratio analysis and knowing the company's financial capabilities that reflect work performance in a certain period. Kaplan [6] grouped the measurement of company performance into four perspectives, namely finance, marketing, learning and growth, and innovation. Stock return results from profits obtained by shareholders on the investments they have made, which consists of dividends and capital gains (losses). Stock return is one of the factors supporting the interest of shareholders to carry out investment activities, Gitman, according to Widnyana (2012) can be calculated by the following formula:

$$
\begin{aligned}
& \mathrm{R}=(\mathrm{Pt}-\mathrm{Pt}-1) / \mathrm{Pt}-1 \\
& \mathrm{R}=\text { Return } \\
& \mathrm{Pt}=\text { Share price period } \mathrm{t} \\
& \mathrm{Pt}-1=\text { Share price period } \mathrm{t}-1
\end{aligned}
$$




\subsection{Corporate Governance}

the role of corporate governance to the relationship between capital structure and value, we must describe this concept. The purpose of corporate governance is to ensure that opportunistic behavior does not occur by reducing and moderating agency problems that may involve agents (managers) and various principals (shareholders, debt holders, employees, suppliers, clients, etc.) or principals. (main entrepreneurs) and various agents (managers, employees, investors, etc). In addition, it facilitates the creation of specific skills needed in strategic decisions (incentives for firm-specific investments) and limits the problem of asymmetric information.

Corporate governance is a very broad, complex, and problematic concept, which is very relevant, although difficult to define, due to the multiple dimensions within it (Zingales, 1998, Becht et al., 2002). Corporate governance can have two meanings, depending on whether the greater emphasis is placed on the instruments used to allocate and manage power within an enterprise, or on the role of institutions and external mechanisms that control the efficiency of corporate activities. This can be defined as:

- a system of how decision making power is distributed within the firm, so to overcome problems of contract incompleteness between different stakeholders (managerial or internal corporate governance

- a set of rules, institutions, and practices developed to protect investors from entrepreneurial and managerial opportunistic behavior (institutional or external corporate governance.

\subsection{Capital Structure}

Capital structure is most important in the company, this is because capital is the beginning of running a business. Capital that companies use in running a business can be obtained from various sources, namely, own capital from company owner or shareholder, or it could be from a loan or debt. If the company's assets are greater than financed by debt rather than capital, then the role of investors declines. The company is considered unable to maintain financial balance in use between the amount of available capital with the required capital.

The agency theory postulates that: because in the end every people are concerned self-interested, then they will have a conflict of interest, at least in some issues, when they are trying to get involved in the cooperative relationship (Jensen 1994). Agency conflict can be reduced. Techniques to reduce agency conflict can be divided into two namely the internal mechanism and external mechanism. Second The mechanism is the same, that is, to align goals managers and shareholder goals (Depken et al. 2006).

\section{a. Agency Theory}

This theory was put forward by Michael C. Jensen and William H. Meckling in 1976 (Horne and Wachowicz, 1998 in Saidi, 2004), which states that management is an agent of shareholders, as owners of the company. Shareholders expect agents to act on their behalf thereby delegating authority to agents.

\section{b. Signaling Theory}

According to Brigham and Houston (2001), A signal or signal is an action taken by the company's management that provides instructions for investors about how management views the company's prospects.

\section{c. Pecking Order Theory}

Pecking order theory assumes that the company aims to maximize shareholder welfare. The company tries to issue securities first internally, retained earnings, then low-risk debt, and finally equity (Myers, 1984 in Perminas Pangeran, 2004).

\section{d. Trade-Off Theory}

The concept of trade-off in balancing theory is balancing the benefits and costs of using debt in the capital structure so it is also known as the trade-off theory (Brigham et al, 1999 in Kaaro, 2003). Based on the theory of Modigliani and Miller (1996) in Adler Haymans Manurung (2004), the greater the debt used, the higher the firm value.

\section{Methodology/Materials}

Moderating variables are variables that strengthen or weaken the relationship between one variable and another as well as control variables as measured by company age, company size, leverage, and company growth. So this regression analysis with Moderated Regression Analysis (MRA) is this test transfers the hypothesized variables as moderating variables with independent variables. In this MRA test, the regression equation model is formulated as follows:

$Y=a+b 1 X+b 2 Z+b 3 X Z+e$ 
Information

$Y=$ dependent variable

$X=$ independent variable

$Z=$ Variable hypothesized as moderating variable

$S R=\alpha+\beta_{1} D A R+\beta_{2} C A+\beta_{3} C S+\mu$

$S R=\alpha+\beta_{1} D A R+\beta_{2} S B I+\beta_{3} C A+\beta_{4} C S+\mu$

$S R=\alpha+\beta_{1} D A R+\beta_{2} S B I+\beta_{3} D A R x S B I+\beta_{4} C A+\beta_{5} C S+\mu$

\section{Results and Discussions}

\subsection{Descriptive statistics}

\begin{tabular}{|c|c|c|c|c|c|}
\hline $\mathrm{N}$ & & & & & \\
\hline $\mathrm{O}$ & Variable & Min & Max & Means & SD \\
\hline & & $\begin{array}{c}- \\
61.3\end{array}$ & & & \\
\hline 1 & SR (\%) & 2 & 314.29 & 10.46 & 64.32 \\
\hline & $\mathrm{CaS}$ & & & & \\
\hline 3 & (index) & 0.01 & 0.93 & 0.40 & 0.23 \\
\hline 4 & DKI (\%) & 0.50 & 60 & 38.11 & 14.75 \\
\hline 6 & CA (year) & 5 & 46 & 23.50 & 13.60 \\
\hline 7 & CS (Rp. T) & 0.15 & 131 & 25.16 & 26.54 \\
\hline
\end{tabular}

In the table above, it can be seen from the results of research data observations of 20 main sector companies throughout 20192020. It is known that the data description for the variable SR of the lowest data distribution (Min) is -61.32 to CS (Rp.T) of 0.15 and the highest SR (Min.) Max) of 314.29 to CS (Rp.T) of 131 per share.

\subsection{Normality Test}

\begin{tabular}{|c|c|c|c|c|c|c|}
\hline \multirow[b]{2}{*}{ No } & \multirow[b]{2}{*}{ variable } & \multirow[b]{2}{*}{ A sig KS } & \multirow[b]{2}{*}{ Cut off } & \multirow[b]{2}{*}{ Decision } & \multicolumn{2}{|c|}{ Transformation } \\
\hline & & & & & $\operatorname{Ln}$ & Decision \\
\hline 1 & SR & 0.000 & 0,05 & not normal & 0.954 & normal \\
\hline 3 & $\mathrm{CaS}$ & 0.244 & 0,05 & normal & & \\
\hline 4 & DKI & 0.055 & 0,05 & normal & & \\
\hline 6 & CA & 0.153 & 0,05 & normal & & \\
\hline 7 & CS & 0.002 & 0,05 & not normal & 0.099 & Normal \\
\hline
\end{tabular}

The table above shows that the dependent variable is smaller than \pm 2.59 , namely for the Stock Return (SR) variable with an LN of 0.954 and also the Capital Structure with an A sig KS value of 0.244 , which means that the value of the variable $y$ is much smaller than the limit value of $\pm 2,59$. Thus, it can be concluded that the results of the normality assessment of the research data used in this study are normal according to the skewness model, which means it is very feasible to be used in subsequent estimates. 


\subsection{Model Fitness}

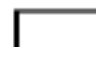

\begin{tabular}{|c|c|c|c|c|c|c|}
\hline & $\begin{array}{l}\text { Residual } \\
\text { Total }\end{array}$ & $\begin{array}{l}56,835 \\
74,070\end{array}$ & $\begin{array}{l}22 \\
25\end{array}$ & 2,583 & & \\
\hline 2 & $\begin{array}{l}\text { Regression } \\
\text { Residual } \\
\text { Total }\end{array}$ & $\begin{array}{l}17,418 \\
56,652 \\
74,070\end{array}$ & $\begin{array}{r}4 \\
21 \\
25\end{array}$ & $\begin{array}{l}4,355 \\
2,698\end{array}$ & 1,614 & $.208^{\circ}$ \\
\hline 3 & $\begin{array}{l}\text { Regression } \\
\text { Residual } \\
\text { Total }\end{array}$ & $\begin{array}{l}19,166 \\
54,904 \\
74,070\end{array}$ & $\begin{array}{r}5 \\
20 \\
25\end{array}$ & $\begin{array}{l}3,833 \\
2,745\end{array}$ & 1,396 & $.268^{d}$ \\
\hline
\end{tabular}

a. Dependent Variable: LnSR

b. Predictors: (Constant), LnCS, CA, DAR

c. Predictors: (Constant), LnCS, CA, DAR, DKI

d. Predictors: (Constant), LnCS, CA, DAR, DKI, DARxDKI

\section{a. Simultaneous test}

The $\mathrm{F}$ test is used to find out the independent variables and the moderating variable of Corporate Governance together have a significant effect on the variables used or used to determine whether this model can predict the variables or not, from the estimation results. The value of the SR Model, Company performance, and Capital structure probability F (2,224), $(1,614),(1,396)$ is small from $=0.05$. Thus, the independent variable has a significant effect on the company's performance.

\section{b. The coefficient of the determinant (R2)}

The coefficient of the determinant is used to measure how big the proportion of variation of the independent variables together affects the dependent variable. From the results of data processing, it was found that the ROA 1 model with an R2 value of 0.07386 showed that the independent variables (KD) and control variables (LV, GP, UMP, and UK affected the company's performance by $73.86 \%$ while the remaining 26.14 was influenced by other factors.

\subsection{Model Power}

\begin{tabular}{|l|r|r|r|r|r|}
\hline \multicolumn{7}{|c|}{ Model Summary } \\
\hline Model & R & R Square & $\begin{array}{c}\text { Adjusted R } \\
\text { Square }\end{array}$ & $\begin{array}{c}\text { Std. Error of } \\
\text { the Estimate }\end{array}$ & $\begin{array}{c}\text { Durbin- } \\
\text { Watson }\end{array}$ \\
\hline 1 &, $482^{\mathrm{a}}$ &, 233 &, 128 & 1,60730 & \\
2 &, $485^{\mathrm{b}}$ &, 235 &, 089 & 1,64248 & \\
3 &, $509^{\mathrm{c}}$ &, 259 &, 073 & 1,65687 & 1,930 \\
\hline
\end{tabular}
a. Predictors: (Constant), LnCS, CA, CaS
b. Predictors: (Constant), LnCS, CA, CaS, SBI
c. Predictors: (Constant), LnCS, CA, CaS, SBI, CaSxSBI
d. Dependent Variable: LnSR

From the autocorrelation test above, it can be seen that the DW value is processed above. Therefore, the DW value is in an area without a decision, so that in that area there is no autocorrelation. Thus the model in this study does not contain the problem of autocorrelation.

\subsection{Regression Result}

Based on the output on the coefficient, it can be seen that the TOL (Tolerance) value of the variables CAS, CA, LnCS, SBI, CASxSBI. Each is smaller than the TOL Value of 0.10. while VIF (Variance Inflation Factor) 10 is smaller than CAS, CA, LnCS, SBI, CASxSBI, it can be concluded that the variable does not occur multicollinearity.

\section{Conclusion}

The current study aimed to investigate the relationship between capital structure and company performance which is moderated by public ownership as a proxy of corporate governance. We apply the agency theory to underpin these relationships. A moderated regression analysis to accept or reject the hypothesis was adopted. The findings show that company performance which is measured by Stock return is about $42.99 \%$ on average. In addition, capital structure is about 39,73\%, with Supervisory Board Independence of $38,11 \%$. The mean value of company size is Rp 26.54 Triliun with company's age is 13.60 years old. The findings of the study also revealed that there is no effect of Capital structure and Performance, Corporate Governance, and Performance. Also, it was found 
that there is no role of Corporate Governance in moderating between capital structure and performance, and there is a negative effect of Company size on performance.

\section{References}

[1] Asyyati, N. F. (2021). Pengaruh Tata Kelola Perusahaan terhadap Struktur Modal dengan Gender Diversity sebagai Variabel Moderasi (Doctoral dissertation, UNIVERSITAS AIRLANGGA).

[2] Kaplan R. S. and Norton, D. P. (1992) Harvard Business Review KaplanAndNorton(Bala - Onbekend, Harvard Bus., vol. 70, 71-79.

[3] La Rocca, M. (2007). The influence of corporate governance on the relation between capital structure and value. Corporate Governance: The international journal of business in society.

[4] Shleifer A. W and Vishny M (1997)Surveycorpgov.Pdf, The Journal Of Finance, vol. 52, no. 2. 737-783.

[5] Schorsch, T., Wallenburg, C. M., \& Wieland, A. (2017). The human factor in SCM: introducing a meta-theory of behavioral supply chain management. International Journal of Physical Distribution \& Logistics Management.

[6] Susanti, Y., Mintarti, S., \& Asmapane, S. (2018). Pengaruh struktur modal, kinerja keuangan perusahaan, ukuran perusahaan dan kualitas auditor eksternal terhadap nilai perusahaan pada perusahaan manufaktur yang terdaftar di bursa efek indonesia. AKUNTABEL, 15(1), 1-11.

[7] Widnyana, K. (2012). Bambu dengan berbagai manfaatnya. Bumi Lestari, 8(1), 1-10. 